\title{
Political Contestation of Local and National in the Implementation of Law No. 6/2014 in Public Spaces and its Implications on Social Institutions in West Sumatera
}

\author{
Tamrin $^{1}$, Afrizal $^{2}$, Helmi $^{3}$, Asrinaldi $^{4}$ \\ $\left\{\right.$ tamrin@soc.unand.ac.id ${ }^{1}$, afrizal_2002au@yahoo.coml ${ }^{2}$, helmi59pdg@yahoo.com ${ }^{3}$ \}
}

Universitas Andalas, Indonesia ${ }^{1,2,3}$

\begin{abstract}
Politics can be interpreted as an interpretive struggle about how space is realized as a place of culture and identity. The following article describes the efforts of the national government to build local identity through decentralization policies and regional autonomy, in order to open up public spaces for the contestation of identity and culture of diverse local communities in Indonesia. Based on the using of qualitative methods and using an ethnographic approach, we found that the decentralization policy implementation of Law No. 6/2014 on Villages in Indonesia produced several forms of political contestation between national governments and local communities, including in the form of; first, the institutional design of village governance; second, the process of selecting village heads; third, the tenure of the village head.
\end{abstract}

Keywords: Political Contestation, Public Space, Social Institution, Indigenous People.

\section{Introduction}

Political contestation in the interpretive struggle for identity or culture in a region is influenced by government policies, decentralization policies to delegate the authority of the central government to regional governments can transfer the form of national identity to local identity [1]. The identity crisis occurs in the area of national society rather than the local communities, the integration of national society with global society raises the problem of the nation-state as a cultural and identity unity [2]. This form of transfer of authority from the central government to regional governments not only reduces central government affairs, but also can fill public space with various forms of local community identity.

Some ideas about this political identity [3], including (1) the decision-making process involves direct participation in important issues in social, economic, political and institutional lives; (2) the arrangement of ownership of state-owned enterprises in democratic process; (3) the decision-making power based on those affected by the decision as the notion of universal pluralism

Changing location of local autonomy policy from the district/city level to the provincial level is the content of amendment of Law No. 22/1999 becomes Law No. 32/2004, although this change obscures the implementation of regional autonomy [4]. Political contestation occurs more in the provincial government area than in the village government area. The provincial government is required to exercise the authority decentralized by the central 
government, as well as being an arena of political contestation of various ethnic identities and cultures. There is a shift in public space of political contestation from the city/district level to the provincial level in the implementation of decentralization policies in Indonesia [5].

The decentralization policy undertaken by the government since 2001 resulted in changes in the form of village management in line with the identity and culture of the community's environment, as well as reducing the dominance of central government oversight [6]. There are several forms of management change in 7400 villages caused by the implementation of this decentralization policy [7], including: (a) reducing the dominance of the central government management authority; (b) provide space for cultural diversity and response to local aspirations; (c) carrying out separation of powers by forming a Village Representative Council or village council (BPD) which is directly elected; and (d) accountability of village heads to BPD.

The purpose of the decentralization policy is to carry out broader reforms, including through strengthening community institutions to be more representative and accountable as means of revitalizing village development. However, many villages have not made the desired changes. Therefore, the purpose of implementing Law No. 6/2014 among them is to overcome several problems of village development, including increasing the budget allocation of village funds and improving village governance. Law no. 6/2014 was passed by the government in January 2014, this law is a continuation of the decentralization policy carried out by the Indonesian government since 2001 [8].

Law No. 6/2014 concerning Villages is a substitute for part of the contents of Law Number 32 of 2004 governing villages, particularly Article 2000 to Article 2016. Unlike Law Number 32 of 2004, Law Number 6 of 2014 provides an opportunity to the region to form a village (government) based on customs according to the origin rights of the local customary law community unit, in addition to the ordinary (administrative) village. The opportunity to form a traditional village was utilized by the Regional Government of West Sumatra Province by issuing Perda No. 7/2018 concerning Nagari [9], so that the form of a nationally regulated village could be developed in the form of Nagari as the cultural identity of the Minangkabau people as the majority ethnic in this area. Regional Regulation on Nagari in lieu of Regional Regulation of West Sumatra Province Number 2 of 2007 concerning the Principles of Nagari Government. Through this new regulation, Nagari identity as a village governed by customary law returned

Politics is not only the question of spatial mastery, but it is also a competition for what is personal and what is public [10] Politics can be interpreted as an interpretive struggle, about how the space is realized as a cultural and identity container? What are the limits? How are political ideas and practices being evaluated? Some of these questions put politics not only as a matter of spatial control, but also the question of how the space is defined with the merger of social and geographic spaces, the nation's country and community are conceptualized.

\section{Research Methods}

This study aims to explain the implementation of governance at the local level, as well as using ethnographic approaches and qualitative methods. The purpose of using the qualitative method used in this study is to obtain more detailed information on the implementation of governance at the local level [11], in order to answer the question of why and how the form of national political contestation with the community contained in the application of Perda No. 
8/2017 in West Sumatra Province. In order to gain knowledge of the context and culture that underlies the form of national political contestation activities with local people, the observations are made to the nagari which is the location of the research. Nagari in West Sumatra. Next to obtain the answers to the questions of this study is to conduct in-depth interviews with implementing actors Perda No. 8/2017, including the Governor of West Sumatra, the Chairperson of the West Sumatra Provincial Parliament, Regent/Mayor of the Regency/City, and the Village Head.

\section{Results and Discussion}

\subsection{Political Contestation}

The difference between private interests and public interests is in the area of economic activity and political activity. Personal interests are carried out in the area of economic activity while public interests are carried out in the political sphere and involve many people [12]. Understanding the public as an area of interaction has a dual understanding, including the understanding of the public as a form of response provided by the community environment to efforts to meet personal needs [13]. This response explains the public understanding as an arrangement of the common interests of individuals in society, and distinguishes between "public life" as a public understanding is "non-political" with "public affairs" as a public understanding that is "political".

The function of social institutions is to connect between community expectations with the assumption that $r$ other people behave the same as they expected, this function can guarantee certainty of attitudes and actions taken by others to create efficiency in the management of "public life" as a non-political domain and "public affairs "in the political sphere. In this case there are playing institutions and informal institutions in the local community, official institutions are a form of written rules and informal rules are unwritten rules that live in the community.

Members' perceptions about the cost of losses or profits obtained from institutions affect the form of structural strength in binding members within the institution, this clarity of perception encourages members to connect with the institution. The formation of cognitive institutions resulting from human intersubjectivity and individual interpretation can result from the selection process in conducting attention, judgment, and the formation and categorization of concepts and attributes and emotions at the individual level [14].

The difference between the public and private areas described from the difference between the country's territory and civil society, the public is the state institution and civil society is a privately financed area to satisfy their self-interest. Civil society as a "public" territory, political form is the transfer of private affairs in the public area [15]. The implications of political understanding as public affairs creates to positive or negative political views, political public nature gives birth to positive views as public affairs and supported by the view that politics is conducted through the interaction of independent and equal citizens.

The weakness of the government approach in explaining political understanding is that it ignores input from the public environment, and ignores the interests of the private sector and society that are outside the government sector [16]. Therefore, the understanding of politics as a form of government is to ignore the notion of the state as a political structure that is broader than the aspects of carrying out these government activities. As a social process then politics 
are present in the form of daily activities as well as placing them as capital letters (P) in academic studies and not (p), understanding politics as the various associations ranging from chaos to the form of "dirty".

Allocation of values that bind the community through authority as the focus of political science is related to the state, power and conflict resolution [17]. The state's relationship with the allocation of values is accidental, allocation is done through state institutions and carried out by the state apparatus. National political contestation with local communities in influencing the social institutions of the Nagari community can be explained from 4 layers, including. (1) informal layers that bind people's behavior and are durable, this layer consists of religious norms, customary norms and community habits; (2) layers outside the evolution and design of social institutions, such as official rules for managing government; (3) rules that can provide benefits as well as prevent conflicts that occur between all parties, such as the form of administrative rules resulting from various forms of agreements and contracts conducted together in order to prevent conflicts; (4) operating rules outlined for a modern organization, in order to regulate the allocation of resources contained in the community [18].

\subsection{Social Institutions}

There are several approaches used to explain the role of local knowledge in institutional development, including; rational approach, historical approach, sociological approach and discursive institutional approach [19]. These four different approaches can be used overlapping one another, without separating the use of one approach from another to explain a social institutional phenomenon. The understanding of institutions according to the rational approach is as a result of rational choices of individuals, in order to produce benefits to meet their desires and interests. Institutions are needed in order to reduce uncertainty and encourage their desire to fulfill the desires and interests of the individuals concerned [20]. This rational approach is used to explain the function of social institutions in local communities in Nagari, and is used to explain the knowledge of actors about the impact of institutions created by the community.

There is a difference between the rational approach and the sociology approach, the sociological approach explains the role of institutions in shaping individual behavior. It takes symbolic understanding and the purpose of using these symbols in institutions, in order to explain human behavior in institutions. The purpose of the behavior is in order to comply with all forms of rules and laws governed by a social institution. The historical approach explains the form of development of a social institution in Nagari society, and explains the difference between the social institutions of the local Nagari community and other Nagari local communities. The historic approach used by local communities in Nagari is to explain the understanding of social institutions as a result of daily activities carried out by the nagari community.

The discursive approach used by the Nagari local community is to explain the process of interaction that results in the sharing of ideas, and seeks to provide legitimacy to the ideas conveyed in the institution through a logical form of communication. The role of social institutions for the local Nagari community is as a discourse to form a framework of thinking, in order to identify ideas that are not appropriate to be accepted in regulating the behavior of members of indigenous peoples. Although the institution is a product of the history and cultural context of the community, it can be used to fulfill their desires and interests through the formation of ideas and legitimacy. However, the various understandings used by the nagari community in spite of the institution are a product of the history and cultural context of the 
community which can be used by individuals for their interests through the formation of ideas and legitimacy.

From these ideas explain the role of social institutions resulting in the view that institutions are not easily changed by the desires and interests of individuals in society. The role of the institution is to direct the behavior of members in accordance with the direction and policies of the institution, based on incentives or sanctions given for deviations committed. The role is carried out through the knowledge of cognition contained in these institutions, as well as normative and regulative rules that bind members of these social institutions. The normative role functions as the norm or value that determines the desires or choices of individual interests, while the regulative aspect functions as a mechanism to regulate institutional behavior.

\subsection{Formulation of Perda No. 7/2018}

Perda (The Regional Regulation) No. 7/2018 concerning Nagari is in lieu of Regional Regulation of the Province of West Sumatra Number 2 of 2007 concerning the Principles of the Nagari Government, Nagari as a customary law community unit is returned to its identity as the leading government organizer based on customary law. Correspondingly, the adat holders in each Nagari were restored as Nagari government administrators, no longer as adat institutions that were exiled from government affairs.

This Perda is also known as the first Indigenous Village Law in Indonesia, and was formulated through a comparative study conducted by the local government to various regions that have customary villages, such as Bali and South Sulawesi Provinces. ${ }^{1}$ The process of drafting this Perda is the longest drafting process for a Perda in West Sumatra Province, and involves 43 public meetings and consultations conducted by the local government with various indigenous community leaders and other organizations.

The process of formulating this Perda is done more than 1 year after the enactment of Law Number 6 of 2014 which only gives a year grace period for district/city governments to establish the unity of customary law communities as traditional villages that organize leading governments based on customs. Therefore, the community is of the opinion that the process of drafting this Perda is carried out in a hurry, without going through a process of focus group discussion with the local community. The nagari community in West Sumatra consists of various families, each family has various groups, each group has various tribes, each tribe has representation in adat institutions. The function of an adat institution is to regulate the implementation of adat which is in line with the environment of the local indigenous community (Adat Salingka Nagari)

The form of public consultation is a prerequisite for the formulation of a policy, so that local governments can listen to the views of various stakeholders related to the contents of the regulation. However, the public consultation carried out by the local government did not involve all community members in Nagari in West Sumatra Province. The non-involvement of the Nagari community in this consultation process places the contents of the Perda biased by the government's perception of Nagari, as explained by the Chairperson of the Nagari Sikucur Institution (KAN) that public consultation on the formulation of the Perda does not involve the Nagari community as owners of community cultural capital. ${ }^{2}$

\footnotetext{
${ }^{1}$ Interview with the Head of the Village Community Empowerment Office, West Sumatra Governor's Office, March 6, 2019.

${ }^{2}$ Interview with Sikucur village head, Pariaman district, 26 August 2019.
} 
However, the regional government explained that the non-involvement of the nagari community in the public consultation process carried out by the government was caused by the diversity of interests and values inherent in the community. The purpose of the formulation of a regional regulation is to unite the various interests and diversity of values contained in society, and can be derived in the form of specific norms and ethics that are in line with the daily interests and values shared by the community. Therefore, the public consultation process carried out by the government is limited to only involving community leaders who have local knowledge about community adat (customs).

\subsection{Political Contestation of Perda No. 7/2018}

The disobedience of the city government to the Regional Regulation of the Province of West Sumatra Number 2 of 2007 certainly becomes a special note in the historical development of the Nagari government in the West Sumatera. Not all regencies/cities in West Sumatra Province adhere to the mandate of Provincial Regulation Number 2 of 2007. All cities in West Sumatra continue to maintain kelurahan as the foremost form of government. Even in two cities, namely Sawahlunto City and Pariaman City, two leading government systems have been applied to the Nagari people, some of which continue to use the kelurahan, and some even maintain villages

Perda No. 7/2018 contains the strengthening of traditional institutions as community institutions, so that they are more responsive and accountable in the process of organizing the Nagari government. This Perda on Nagari specifically in the three content matters, namely the institutional arrangement, the filling of positions, and the term of office of Nagari's head. There is a traditional institution in the form of the Nagari Customary Court as a community dispute resolution agency in Nagari, besides that there are Manti Nagari, Bandaharo Nagari, Dubalang Nagari as apparatus who assist the administration of the Nagari government. This Nagari government apparatus reflects a form of village-adat government system, although it performs the same function as the previous village government system.

There is a difference in the way the village head is chosen and Kapalo Nagari (head of Nagari), Kapalo Nagari is chosen indirectly through mamak ninik representatives found in traditional institutions. The function of adat institutions is not only to carry out the customs and conduct supervision of the implementation of the Nagari government, but also to carry out the selection and selection process of Kapalo Nagari, as explained in Article 7 (2)[9], that the Nagari Customary Duties have the following authority: (a). selecting and appointing Kapalo Nagari by deliberation and consensus; (b) channeling the aspirations of the Nagari people; (c) supervise the implementation of Nagari customs and culture; (d). requesting accountability for the implementation of the Nagari Government to Kapalo Nagari; and; (e). preserving customary and cultural values according to the Adat Salingka Nagari (local tradition).

The adat institution is a mandate of popular sovereignty carried out by Kapalo Nagari, there was a change in the Kapalo Nagari electoral system from a direct electoral system to an indirect electoral system. Arrangements for the implementation of the Village Head election system carried out directly by Law No. 6/2014 is considered to provide an open space for political participation, as well as to further ensure the electability of Kapalo Nagari who has expertise in managing the Nagari government system. But, the implementation of Perda No. $7 / 2018$ is considered to reduce the political rights of the community in determining leaders, and is considered as a form of decline in the implementation of political democracy at the Nagari level. 
The authority of traditional institutions in nominating and electing Kapalo Nagari not only reduced Kapalo Nagari's leadership capabilities, but also strengthened the conflict instability between the tribes that existed in carrying out the functions of traditional institutions so far. The implementation of the functions of traditional institutions is influenced by the various interests of each tribe, as well as giving rise to implications for the alignment of each tribe towards the proposed and chosen Kapalo Nagari ${ }^{3}$ Changes to the Kapalo Nagari electoral system not only reduce the political participation of the community, but also create leadership that contains elements of representative nepotism of each tribe.

The implications of the change in the Kapalo Nagari electoral system from the direct electoral system governed by Law no. 6/2014 with an indirect election system regulated by Perda No. 7/2018 is a reduction in the number of villages, the election of Kapalo Nagari by adat institutions can only be done for 1 Nagari who has 1 adat institution. The implementation of the electoral system does not directly allow the formation of several villages in one adat institution, the function of adat institutions is to oversee the implementation of customs without having authority in the selection of Village Heads. The change in the Kapalo Nagari electoral system indirectly was to integrate several villages that had been split from a parent Nagari into 1 Nagari which had 1 traditional institution.

Merging several villages into a Nagari has implications for reducing the amount of village fund allocation, implementing a direct election system for the Village Head allows each village to obtain an allocation of village funds of 1.3 billion rupiah/year. However, the total allocation of village funds will be reduced by the merging of several villages into a Nagari. Although the Regional Government of West Sumatra Province has promised an additional allocation of village funds from the Provincial APBD (Regional income and expenditure budget) of 250 million rupiah/year to villages that can implement this village-adat government system, the amount of assistance for allocating village funds is smaller than the amount received by each village. from the central government. ${ }^{4}$

There was public rejection of the policy of the Regional Government of the Province of West Sumatra in implementing Perda No. 7/2018 concerning desat-adat, such rejection was made by the Wali Nagari Forum (Forwana) of Pariaman Regency. on the socialization of this Perda on November 7, $2018^{5}$ This rejection is based on the reason that the West Sumatra Provincial Government's policy in formulating the contents of this Perda does not reflect the aspirations of the community in demanding economic and political needs, due to the formulation of the Perda which is only carried out according to constitutional procedures but does not contain substantive economic and political democracy

\subsection{Discussions}

The form of political contestation in the government's decentralization policy is a struggle to interpret public space according to the content of the identity and culture of each actor, as well as how the public space is defined to contain social and geographical dangers in it. Political contestation occurs when political understanding changes from the form of value allocation made by the government to the understanding of public space, the change places public space to be open to various forms of rules in the state, such as formal rules in government or informal and religious rules and customs in society.

\footnotetext{
${ }^{3}$ Interview with Assistant 1 for Government, Pariaman District, 17 September 2019.

${ }^{4}$ Interview with Bamus Chairperson, Batu Kalang Village, Pariaman Regency, 22 August 2019.

5 interview with the Chairman of Forwana, Pariaman Regency, 26 August 2019.
} 
In implementing procedural democracy, the government consults with a number of views before making legislative proposals, and discusses the bill before the vote; Whereas in the implementation of substantive democracy there are procedures for placing multiple choice decisions, so that the public can provide insight into the final decision that benefits everyone. There is no predetermined goal as a single logical form used in the implementation of procedural democracy, whereas in the implementation of substantive democracy there are certain predetermined objectives. However, on the other hand the community demands that both the process and the content of the content of the Perda better reflect multiple logic that is in line with the economic and political interests of the diversity of identity and culture of the community.

\section{Conclusion}

The traditional village-adat institutional alignment that is in line with the interests of the identity and culture of the local community, but is carried out through the implementation of procedural democracy, results in the complexity of the problem of the relationship between the national government and the local community in 3 political issues, including; (1) the extent to which the policy can represent the security of the identity and culture of the community; (2) how far the authority of adat institutions in determining the election of Kapalo Nagari does not reduce the political rights of the community; (3) how far the authority of this customary institution can be evaluated by the community and the national government, so that it does not conflict with community political rights and management of village allocation funds submitted by the central government to the regional government.

Acknowledgement. The author would like to thank the various parties who have helped fund this research, especially to the Ministry of Research, Technology and Higher Education through LP2M Andalas University who are willing to fund this research through the Basic Research (RD) Scheme of BOPTN 2019 funds based on research contract No. T/7/UN.16.17/PT.01.03/RD-Science Innovation/2019 dated July 15, 2019.

\section{References}

[1] K. Terlouw, "Transforming identity discourses to promote local interests during municipal amalgamations," GeoJournal, vol. 83, no. 3, pp. 525-543, 2018.

[2] K. Terlouw, Local Identities and Politics, Negotiating the Old and the New, First. New York, 2017.

[3] R. H. Chilcote, "Comparative inquiry in politics and political economy: Theories and issues," Comparative Inquiry in Politics and Political Economy: Theories and Issues. Westview Press, Oxford, pp. 1-216, 2018.

[4] R. Istania, Dinamika Politik Lokal. Jakarta: STIA-LAN, 2009.

[5] M. S. Grindle, Going Local Decentralization, Democratization, and the Promise of Good bGovernance. Princeton: Princeteon University Press, 2007.

[6] J. Harriss, K. Stokke, and O. Törnquist, Politicising Democracy: The New Local Politics of Democratisation. New York: Palgrave Macmillan, 2005.

[7] H. Antlöv, A. Wetterberg, and L. Dharmawan, "Village Governance, Community Life, and the 2014 Village Law in Indonesia," Bull. Indones. Econ. Stud., vol. 52, no. 2, pp. 161-183, 2016.

[8] I. C. Watch, "Outlook Dana Desa 2018 Potensi Penyalahgunaan Anggaran Desa di Tahun Politik," Jakarta, 2018. 
[9] S. B. Gubernur, "Penjelasan Atas Perda Prov Sumbar Tentang Nagari," 2018.

[10] R. W. Hefner, Remaking Muslim Politics; Pluralism, Contestation, Democratization. Princeton: Princeteon University Press, 2005.

[11] N. K. Denzin, Y. S. Lincoln, and ...[et al], "Collecting and Interpreting Qualitative MaterialsSAGE Publications,.”p. 710, 2013.

[12] D. P. L. James A Corporaso, Teori-Teori Ekonomi Politik, Third. Yogyakarta: Pustaka Pelajar, 2015.

[13] L. L. and E. Vedung, Politics as Rational Action. Dordretch: D. Reidel Publishing Company, 1980.

[14] D. Friel, "Understanding institutions: different paradigms, different conclusions," Rev. Adm., vol. 52, no. 2 , pp. 212-214, 2017.

[15] H. Arendt, The Human Condition. Chicago: The University of Chiago Press, 1958.

[16] A. Heywood, Poltics, 2nd ed. New York: Palgrave Macmillan, 2002.

[17] D. Easton, "An Approach to the Analysis of Political System," World Polit., vol. 9, no. 3, pp. 383-400, 1957.

[18] P. J. D. Walter W. Powell, The New Institutionalis in Organiztional Analysis. Chicago: Chicago Univrsity Press, 1991.

[19] D. Friel, "Understanding institutions: different paradigms, different conclusions," Rev. Adm., vol. 52, no. 2, pp. 212-214, 2016.

[20] J. Elster, Rational Choice: Readings in Social and Political Theory. New York: New York University Press, 1986. 